\title{
Vagn Greve (1938-2014)
}

\author{
OBITUARY
}

Every once in a while, a major cliff falls off the mountains of Western Norway. No matter how awaited it may have been, the fall is always dramatic. It leaves the ground shaking. The landscape is changed for an entire generation, leaving an empty space. On the 18th of July this year, one of the most monumental cliffs of the Nordic criminal law science fell. Professor Vagn Greve passed away after a long-time illness.

Professor Greve was educated at the Faculty of Law of the University of Copenhagen. In 1965 he received his degree at the institution where he was to spend most of his academic career. He became professor of criminal law at the Faculty in 1992, a position he held until 2008. For a period, he also served as Dean of that institution. During his academic career, he also held positions at Copenhagen Business School, and was connected to the University of Southern Denmark. He also received the degree of doctor honoris causa from the University of Uppsala (1997) and the University of Helsinki (2010).

Professor Greve made a number of significant contributions to Nordic criminal law science. His first work was the criminological study Kriminalitet som normalitet ('Crime as Normality'). He later wrote a number of journal articles and books on criminal law, including the much-appreciated textbooks on Danish criminal law, Det strafferetlige ansvaret ('Criminal responsibility') and Straffene ('The Criminal Sanctions'). Towards the end of his academic career, several other books were produced, such as Forbryderen, medmenneske eller fjende - og andre artikler ('The Criminal, fellow human being or enemy? - and other articles').

Professor Greve's many works have always been imprinted by his outstanding intellectual profile. He early on found a strong interest in criminology and appreciated its importance for understanding and debating criminal law. He also always emphasised 
the importance of legal history. Most of all, however, he has been a stern defender of the ideology of Nordic criminal law and the emphasis it places on humanity and rationality as the guiding principle for criminal policy. In addition to his many publications and lectures, professor Greve made an impact on the Nordic criminal law community in many other ways. He was among the founders of, and an active contributor to, the annual Nordic workshop in criminal law. For us in Bergen, professor Greve was an active supporter and contributor to our young and evolving criminal law environment. He has offered his help and knowledge to a number of us, for which we are deeply grateful. We are all shattered and mourning his loss.

\section{Asbjørn Strandbakken,}

Dean, Faculty of Law, University of Bergen

Jørn Jacobsen

Annika Suominen

Editors-in-chief, Bergen Journal of Criminal Law and Criminal Justice 